\title{
Does blood count? Buying decision-making processes in stepfamilies
}

\author{
László Józsa, Boglárka Eisingerné Balassa
}

Széchenyi István University, Marketing and Management Department, Győr, Hungary

Email address:

jozsal@sze.hu (L. Józsa), eisingerne@sze.hu (B. E. Balassa)

\section{To cite this article:}

László Józsa, Boglárka Eisingerné Balassa. Does blood Count? Buying Decision-Making Processes in Stepfamilies. Science Journal of Business and Management. Vol. 2, No. 6, 2014, pp. 163-169. doi: 10.11648/j.sjbm.20140206.11

\begin{abstract}
The aim of the study is to analyze one of the most relevant, current and interesting courses of social processes. Consumer behavior researches have always been focused on studying and analyzing consumption of different types of families and households. Social processes are influenced by way of life and lifestyle of families, and it is true reverse as well. The process of knowledge transfer is in a patchwork family so complicated and complex, like in a big company. The processes and the problems are same because the different generations. The socialization of children and by this the forming of their way of life and lifestyle, their consumption and buying habits will be printed by the sample in the family. Describing and characterizing the lifestyles of families and family members who are living, raising or holding on as a parent in a patchwork family meet with difficulties. There are so many patchwork families so many kinds of them but one is clear: the way of life and the lifestyle of them is very special, unique and differs from a classical or "nuclear" family. The aim of this article is to describe a new consumer group, to discover the phenomenon, the lifestyle and the consumption habits of the group through lifestyle-researching methods.
\end{abstract}

Keywords: Consumer Behavior, Stepfamily, Family Typology

\section{Introduction}

Nowadays the changing of traditional form of family has been a global social phenomenon. In Hungary half of the marriages end with divorce according to the data of $\mathrm{KSH}$ [1], every six children lives in patchwork family [2]. There are several international researches dealing with the psychical processes in patchwork families [3]; the sociologists research the social reasons and affects of this phenomenon [4]. Marketing experts made also studies related to the patchwork families because the consumer behavior in a specific and complicated family structure shows strong differences between the consumer behavior in stepfamilies and in traditional families [5].

Although these categories at first glance seem to have less influence on the quality and ways of knowledge sharing, the atmosphere within the family and the trust mentioned in the previous chapter are fundamentally influenced by the composition of the family. As a result the worker in the family will inevitably adopt the same behaviour patterns at work as at home

In the international literature of sociology and psychology the family form is called patchwork family where there are not parents and their common children but which arises from "fusion" of different family parts. The patchwork families are called in the Hungarian language "mosaic families" sprang from the same idea: the markings of a mosaic evolve with putting together the originally separated colorful stones. The stepfamily, the blended family or the reconstituted family are also often used. In our country first of all the psychology and some sociological sections are dealing with the patchwork families. The experts dealing with family therapy deal with this area but unfortunately only its foreign (mainly German and English) literature is significant. The patchwork family is a family where one or both part of the parents has already a child from their previous relationships. The part of the couple who is not the biological parent of the child is called stepparent (stepmother or stepfather) [6]. The definition of the patchwork families approached form different point of views:

- Blended family is a family which evolved from separated families with marriage or other kind of relations [7].

- Reconstituted family: is the sociological interpretation of the relationship (from marriage, coexistence or common-law marriage) of two adults who already have children from prior relationships.

A new family that is formed from remains of a broke-up 
family [8].

The patchwork families were firstly mentioned in Germany in 1984 [9]. Formerly such families have arisen from the remarriage of widows with children but the rising of number of the divorces has emerged today's patchwork families [10]. According to Sager (1983) the patchwork family is formed from marriage (or coexistence) of two partners and at least one of them was already married. Visher and Visher (1995) define the patchwork family as a symbiosis where at least one of the adults is a stepparent. Those parents who do not live with the family after the divorce play important role in the life of the family [11]. In Hungary Ercsey (2012) highlighted the evaluation of the family life in connection with the quality of life.

The patchwork family differs from the nuclear family not so much seen from wider view but on a closer examination it differs significantly [12]. According to the structural comparison of Visher and Visher [13] was found that these two models differ from each other. The patchwork family shows some similarities with segregated, foster- and adoptive families. Papernow [14] noted two types (a) simple patchwork family-system (one parent-child system and one stepparent) (b) multiple family (two parents-child systems).

Verena Krähenbühl [15] worked out a typology which differentiates who joined the system - the stepfather or the stepmother: (1) Family with stepmother: when a woman joins to a man and his biological child. (2) Family with stepfather: a man joins a woman and her biological child. (3) Multiple patchwork family: two part-families get connection and both partners bring their children from prior relationships. (4) Patchwork families with common child or children: beside the "brought" children there is one or there are more common child/ren in the family. (5) Part-time patchwork family: the children from the prior relationships live with the segregated parent and his/her new partner in certain defined time.

The patchwork families are not as convergent as other families and they have to face with many conflicts because of the differences of certain family members [16]. The children also have less voice in certain decisions because the family members do not want to have a more complicated situation [17]. One of the main sources of difficulties for patchwork family members is that the role expectations are unexplained [18]. These families do not have common history; conflicts can arise related to nursing of a child and to decisions related to things of everyday life. Many researches prove that the children in such families can have more problems like poverty, psychical and behavioral problems, learning difficulties and health problems [19]. One of the most hardly solvable problems is caused by the financial clashes. The family form has impact on the buying decision-making process and on the characteristics of the process [20].

\subsection{Research Questions}

Before starting the research the following questions are defined:

- Does the buying decision-making mechanism in stepfamilies differ from that in traditional families?

- Is it possible to typify the stepfamilies according to the buying decision-making processes?

- Contrary to the former typifying methods in the literature, can we define new stepfamily types according to the characterization above?

\section{Primary Research}

Before starting the research the following questions are defined:

- Does the buying decision-making mechanism in stepfamilies differ from that in traditional families?

- Is it possible to typify the stepfamilies according to the buying decision-making processes?

- Contrary to the former typifying methods in the literature, can we define new stepfamily types according to the characterization above?

We started to elaborate the topic with qualitative research in our exploratory research the individual in-depth interviews were chosen as method. The qualitative research was made with exploratory characteristics to get to know the theme extensively and deeply. The research was made in autumn 2011 when 62 adults living in stepfamilies were asked who are coming from different types of mosaic families (Table 1.)

Table 1. Types of stepfamilies of the interviewees

\begin{tabular}{ll}
\hline Types of patchwork family & Number of the sample (capita) \\
\hline Stepmother & 4 \\
Stepfather & 14 \\
Complex & 18 \\
Common child (stepmother) & 4 \\
Common child (stepfather) & 14 \\
Common child (complex) & 5 \\
Part-time & 3 \\
\hline
\end{tabular}

Source: Own table

We collected the interviewees with the help of snowball sampling [21]. We chose this kind of technique because of the following: people living in patchwork families declare really hard related to the topic thus making focus group interviews proved to be impossible. To conduct the in-depth interviews an interview guide was used which was composed by studying the literature and by a prior research. In favor of getting deeper information in the theme We had a speech with 5 people who lived in patchwork families before making the interview guide.

By making the qualitative research We have two aims: (1) to prepare the quantitative research and (2) to lay down the hypothesis tested during the quantitative survey. In the introduction of this study I presented the typical characterization of stepfamilies which is well-known from the psychological literature.

Using the results of the qualitative research We found it reasonable to make a quantitative research in favor of getting more complete and extended knowledge in the topic and in the research problem. The filling out of the questionnaires and the searching of respondents took place between November of 
2011 and February of 2012. During the research We asked 142 parents living in patchwork families and 184 living in traditional ones - also with the help of snowball sampling.

The majority of the respondents were women (105 women and 37 men filled out the questionnaires). The high proportion of women can be explained by the fact that generally they manage the issues related to the family. The average age of the respondents was 39, the birth date of them ranged from 1955 to 1989.

Table 2.. The presentation of respondents living in stepfamilies in the sample of qualitative research

\begin{tabular}{ll}
\hline Gender & Women 105 \\
\hline & Men 37 \\
Average age & 39 \\
Educational background & $35,7 \%$ higher educated \\
& $32,4 \%$ with graduation \\
& $23,2 \%$ intermediate educated \\
& $7,5 \%$ graduated from primary \\
school
\end{tabular}

Source: Own table

\subsection{Family Typology Approaches According to the Qualitative Research}

The typology of stepfamilies was defined by psychological literature according to the following facts: who joins the family and does he/she bring child/ren to the new family [22] and will born common child/ren from the new relationship [23]. Practically the biological relations in stepfamilies were analyzed in former studies but according to my primary researches I can state that the basis of analysis and of typifying can differ from the former studies.

It is a very important factor in the life of stepfamilies how the adults living in the family are able to solve everyday life-, holiday issued, conflicts and educational questions. Solving these problems does not depend on who joins the family but depends on the values, the attitudes and the communications of parents and children living in the family. We all know stepfamilies which "work well" and others which do not. We can ask the question - Why can we see these differences? If we consider what kind of roles the family members have during a buying decision-making process (lower priced consumer's goods, higher priced capital goods, cars, and holidays) then the mechanism in the families can be seen, too.

Does the wife-mother have voice in decisions related to her non-biological children? Do the families take into consideration the decisions of children not living in the household during organizing a family program? Based on the buying decision-making conflicts and their solving methods we can separate different types of stepfamilies - that approaches the point of the problem from another aspect than the former researches made in the topic.

During the qualitative research We defined one typical type of stepfamilies. The characteristics of these families are the following: the husband is older (whether with one generation) than his partner, typically he was in marriage (or in common-law marriage) when he also had child (or children) who has/have already left or who are now leaving the family. The adult female member of the family lives in her first marriage or in her first longer common-law marriage, they have common child/ren typically who is far younger that the child/ren from the first marriage of the husband. It is a frequent phenomenon in the case of such families that the husband also has grandchild/ren who is at the same age as his child/ren from the second (or third) relationship of him.

The obvious classification of parents living in these families is impossible according to the family life-cycle theories. The mother can be found in the category of couple with child/ren under the age 6 or in the couple with child/ren above the age 6 according to the family life-cycle - we can say that she is in the right phase of life-cycle according to her age. The position of the father is more complicated because based on the family life-cycle theories he has to be found in the phase of older couple with independent children, but he is in one of the two phases mentioned above.

Based on the life-stage marketing [24] we can classify and define the father as well: he can be found in the phase of parents; he takes responsibility for others (child/ren) but he takes it not in that age in which the family life-cycle theories assume it (under the age 35 or between 36-64 ages [25].

The main sources of conflicts in such families are:

- the father is at the top of his carrier but the mother is in the phase of carrier-building, thus different aims and preferences lead the partners;

- the helping family members of the older parent are often missing because of their age - perhaps they are dead this negatively affects also the socialization of the children;

- questions and conflicts related to the child/ren from the husband's former marriage:

- descent,

- buying gifts,

- buying higher priced goods (electronic or technical tools)

- proportion of solving questions in connection with everyday life and living,

- finances of tuition, extra lessons or university studies and its degree,

- participation in events that are very important to the children: marriage, Christmas, birth of grandchildren can lead to many conflicts within the family

During the qualitative research many interviews were made with adults living in such families and We experienced that the 
partners try to handle and solve the problems right but they cannot. Its reasons can be seen from different point of views: first is the diffuse biological relations, and the unexplained roles of stepparents and stepchildren can also lead to here. On the other hand there are the financial questions - the role of stepparent and biological parent not living in the same household as the children in the solution of financial questions. Thirdly, we can mention the big differences and its difficulties in the age between the children living in or out of the family and the adults.

During the in-depth interviews many respondents did not confess that the most important sources of conflicts are the financial questions but making an interview with the president of stepfamilies' association just the opposite turned out. The stepfamilies try to be similar to the traditional families and they do not like to speak about conflicts which developed because of the changes in the structure of the family.

\subsection{Family Typology Approaches According to the Quantitative Research}

Based on our quantitative research there are other typifying aspects, in consideration of special buying habits of stepfamilies. We classified the respondents living in patchwork families into 4 clusters which show strong differences according to their lifestyles. The first question in the questionnaire contained 34 attitude statements which should be evaluated by the respondents on a 1-4 scale. There was an option for "do not answer" and for "do not know". The attitude statements spring from the researches of Zoltán Veres [26]: Lifestyle-based consumer segments in Hungary and was chosen because these scales are already validated.

During characterization of the clusters We considered the results with more than 2,5 average value. We identified the clusters with the help of SPSS 19.0 statistical program and after that We made cross-tabulations in the cases of different clusters, so We could compare the members of the groups and their buying decisions and conflicts. The buying decisions and the characteristics of conflicts originated from them and financial questions were different in the 4 clusters. We will summarize these characteristics of the clusters in the following pages - respect also the family typology questions.

Defining the cluster groups and the other stepfamily types:

\subsubsection{Cluster 1}

Stepfamily works as a traditional one in which the role of child/ren living out of the household is unimportant. Family-oriented, active, tradition follower. To the individuals of this cluster the other's appreciation is important. They are family-centered, they try to manage tasks of life and if they fall, they try it again. For them the respect of traditions and customs is important but they are open to new things, too. They think over their buying decision in advance, the impulse purchase is not characteristic in this cluster but the rational decisions are. They have practical approach.

The majority of the group is higher educated woman, $93 \%$ of them have biological child/ren, and $7 \%$ of them raise stepchild/ren in the household. $35 \%$ of the cluster members said that they have child/ren living out of the household. Regarding their net income per month they have average income (56\% have 70-130 thousand HUF/month, $26 \%$ have 130-250 thousand HUF/month). The women decides alone in the case of consumer goods - lower priced shopping, but in the case of higher priced goods and shopping there is common decision. If we consider the buying decision-making we can see that the women make their own decisions but there are common decisions in case of buying clothes for their partners. The buying decision-making and thus the buying decision-making roles define the status of the family members within the family.

The clothes and buying them are not high priced products that $\mathrm{s}$ why We chose this kind of goods. In case of buying clothes for the children living in the family - independently from the fact whose biological child is the child - the adults decide together or the women decide alone. We can say that the parents do not make distinction between biological and non-biological children within the family in buying decisions. In this cluster the role of child/ren living out of the household is different because the shopping of clothes is the decision of the adult who raises the child thus the biological parent has no role in this case.

The decision about school and education has a great impact on everyday life and on the future of a child; the role in this decision-making process enlightens the parent's influence on the child's life without reference where the child lives. In this cluster this is also a common decision independently from whose biological child within the family is the concerned child. In the case of child living out of the family that parent has the decision who raises him/her. This is surprising because the decision about the education is a very important and significant question.

The paying of phone bills is often a source of conflict; who pays these bills within in a patchwork family can show the roles of members of that family. Similarly to the former shown themes, the common decisions are typical in case of child/ren living in the family but in connection with child/ren living out of the family only that parent pays who raises that child/ren. In reference to the higher priced shopping (above 20.000 HUF) the parents decide together if it concerns the child/ren living out of the family; so the stepparents also have voice in this process. Obviously it is because of the high value of the shopping.

On the whole this cluster tries to behave as the traditional families in case of child/ren living in the family; it is important for them to let this picture see about the family to the outside world. The role of the child/ren living out of the family is a real stepchild-role; the decision-making is in the hand of the parent who raises him/her.

\subsubsection{Cluster 2}

Patchwork family works as traditional one in which the role of child/ren living out of the family is partly dominant. The cluster prefers stable relationship, the members are family oriented, passive and they have attitude of mind. They like to spend their spare time at home; they do not go anticipate 
things. For them spare time is more important than earning money; they prefer to wait for directions also at work than do it spontaneously. They have attitude of mind; they prefer to work in groups than as leader.

It is a female cluster whose members are intermediate educated or studied profession. $92 \%$ of them have biological child, $8 \%$ are raising stepchild/ren and $25 \%$ have child/ren out of the family. They are in the low income category according to their net income per month (58\% earn 70-130 thousand HUF/month; $17 \%$ earn under 70 thousand $\mathrm{HUF} /$ month). In the case of consumer goods we can talk about a basically female decision but the higher priced shopping is a common decision. Buying clothes - lower priced products - is a common decision if the decision is about the clothes of the partner; but if it is about buying clothes for the child/ren living in the family it is the decision of the woman without reference whose biological child/ren is/are the child/ren. In the case of the child/ren living out of the family we can talk about common decision. Thus the members of this cluster take part in some degree in the decision related to the child/ren living out of the family.

The decision about the education of child/ren is basically common but in relation with child/ren living out of the family it is the decision of the child/ren's raising parent. This is the same situation in case of paying the phone bills; probably in this type of patchwork families the parents take part in the life of child/ren living out of the family if the decision is about lower priced products. The decision of the parent who does not raise the child/ren is unimportant in relation with higher priced products or education.

\subsubsection{Cluster 3}

Patchwork family works as traditional one in which the role of child/ren living out of the family is largely dominant.They are surpassingly family-centered, active and they like the novelties. They are open to innovation; they like to try new products and brands often; we can not name them brand loyal buyers. They like to spend their spare time out of home but with their family. Money is important for them; they are impulse buyer related to their buying decisions.

This is the only cluster which is basically a male cluster. Thus we can say that according to the attitude statements one male group of the clusters can be separated. They studied profession or they are intermediate educated; $93 \%$ have biological child/ren, $7 \%$ have stepchild/ren, $21 \%$ have child/ren living out of the family. $50 \%$ of the members have 70-130 thousand HUF/month, $28 \%$ of them have 131-250 thousand HUF/month net income.

In the case of decisions in the family - such as consumer goods or higher priced shopping - the decisions are generally common. The opinion of the cluster members differs from each other in relation with buying clothes for the not common child/ren living in the household: three answers have the same proportion - the parent decides alone, it is the decision of the biological parent and it is a common decision. It was the first cluster where the decisions about the shopping and education related to the child/ren living out of the family are common decisions. There is only one exception: that biological child who belongs to the woman because his/her phone bill is paid by the biological mother.

\subsubsection{Cluster 4}

Patchwork family works as traditional one in which there is no role of child/ren living out of the family. Partner-oriented, passive and the opinion of the outside world is very important for the cluster members. They like to stay at home; first of all their partner is important for them. They don't like to try novelties. They have leading type; they don't like to be in group; they come to a buying decision based on rationality and not on impulses. They are persistent and they are able to cope with difficulties.

The majority of the members are women who are intermediate educated and who have average income. $95 \%$ have biological child/ren, $5 \%$ have stepchild/ren, and the proportion of child/ren living out of the family is relatively high: $38 \%$. We can see a difference between the former clusters and this one in case of buying decision-making within the cluster. There is a female decision not only in consumer goods but also in higher priced shopping. We can talk about common buying decisions if it is about the members of the family but they have no voice in decisions related to the child/ren living out of the family. It is typical for buying clothes, paying phone bills, buying higher priced gifts and they do not bring the child/ren living out of the household on holidays.

This cluster is primarily not family oriented but the partners are important for the members. It is obvious from their buying decisions that they do not take notice of the child/ren living out of the family; they do not regard this child/these children as part of the family. It is surprising that this is true not only for the stepchildren living out of the family but also for the biological children. We also made some in-depth interviews with mothers who told us that their former partners take part in the life of the common child/ren only for an obligatory degree related to the finances of the child/ren.

We do not define a null hypothesis before starting the quantitative research, but according to the research I could define a thesis. The thesis defined by the cluster analysis is the following:

T1: According to the quantitative research of buying behavior/decision-making We can state that the typological approaches used in sociology and psychology can be supplemented by a new aspect. The basis of amendment is the „position/role" within the family of the child/ren living out the family.

\section{Summary}

The patchwork families constitute a research topic first of all on the scientific areas of sociology and psychology. In the Hungarian practice special publications, monographs and handbooks with practical instructions have been published related to sociology and psychology which try to approach the phenomenon from different point of views. Although the 
appearance of patchwork families is not a novelty; they can mean a potential target group for the future's experts because of the growth of their proportion. Searching on the internet there are many companies which advertise their products and services for patchwork families - from games which have an important role in creating the cohesion in families to the realization of the sticky services related to inheritance or insurance. We see the new result of our study first of all that We started to examine such target group in marketing with which the Hungarian researches have dealt only tangentially. In our opinion with the growth of patchwork families an interesting and useful research area will emerge for not only the academic but also for the practical sphere. In our study We introduced that the buying decisions and conflicts of patchwork families differ from those in traditional families because of the structure of the family - which can mean the basis of effective marketing communication.

The practical use of my research can carry interest in several areas (psychology, pedagogy, and marketing). In the society there are many prejudices against the patchwork families (first of all against the stepparents), and the resolution of them supposes an effective social cooperation. The patchwork families and the member of them need to get special attention as they have many conflicts because of their special relational structures. There are also differences related to their buying decisions (e.g.: the rate of children's voice) which should be taken into consideration by marketing experts. The patchwork families aim to avoid conflicts and to live a "traditional" family life thus the marketing communication for them have to transmit acceptance and appreciation - they should not refer straight to the patchwork family. We have to take into account those problems that patchwork families have to face; we should offer such products and services and we should send such messages which can give solution of those problems. The reach of patchwork families is not easy but We think that they would be effectively reached with direct marketing communication through voluntary helper organizations, associations and foundations which can organize these families into groups.

\section{References}

[1] C. J. Sager, H. S. Brown, et al (1983): "Treating the Remarried Family.", New York.

[2] D. Cheal, (2002): "Sociology of Family Life.", Palgrawve MacMillan, Basingstoke.

[3] E. B. Visher, J. S. Visher (1995): „Stiefeltern, Stiefkinder und ihre Familien, Probleme und Chancen." Weinheim und München.

[4] E. Fischer (2005): “Modern mostohák." Saxum kiadó, Budapest, pp. 13-14.

[5] E. Földházi (2009): „Családszerkezet.” Demográfiai Portré, 2009., pp. 99-108.

[6] E. Hetesi, J. Andics, Z. Veres (2007): „Az életstílus kutatási eredmények fogyasztásszociológiai interpretációs dilemmái." p. 120., p. 123. In: Szociológiai Szemle, 2007/3-4, pp. 115-134.
[7] E. M. Hetherington, (1999): "Family functioning and adjustment of adolescent siblings in diverse type of families.", in Hetherington, E.M., Henderson, S.H. and Reiss, D. (Eds), Adolescent Sibling in Stepfamilies: Family Functioning and Adolescent Adjustment, Monographs of the Society for Research is Child Development, Vol. 64, pp. 1-25.

[8] E. Mintel (2005): "Marketing to Families.", Mintel International Group Ltd, London.

[9] Ercsey, I. (2012): Perceived quality of life as sustainable development facet, Journal of Security and Sustainability Issues, International Entrepreneurial Perspectives and Innovative Outcomes, Editors-in-Chief: Rakutis, V.-Mitra, J.-Tvaronaviciene, M., ISSN 2029-7017, 2012. 2(2), pp. 19-30.

[10] G. Allan, G. Crow, (2001): "Families, Hoseholds and Society.", Palgrave MacMillian, Basingstoke.

[11] Gilly - Enis (1982): „Recycling The Family Life Cycle: A Proposal For Redefinition." In: Advances in Consumer Research. Vol 9., pp. 271-276.

[12] J. Tinson, and C. Nancarraow, (2007): "Growing up: tweenagers involvment in family decision making.", Journal of Consumer Marketing, Vol 24. No.3, pp. 160-170.

[13] J. Tinson, C. Nancarrow, I. Brace, (2008): "Purchase decision making and the increasing significance of family types.", Journal of Consumer Marketing, Vol. 25. No. 1, pp. 45-56.

[14] K. B. Rogers, H. A. Rose, (2002): "Risk and resiliency factors among adolescents experience marital transitions.", Journal of Marriage and Family, Vol. 20, No 3, pp. 238-251.

[15] L. Clarke, and H Joshi, (2005): "Children's changing families and family resources.", in Jenson, A.M. and McKee, L. (Eds), Children and the Changing Family: Between Transformation and Negotiation, Routledge Falmer, Abingdon, pp. 15-26.

[16] M. Cockett, J. Tripp (1994): "The Exeter Family Study.", Exeter, University of Exeter.

[17] M. Törőcsik (2011): „Fogyasztói magatartás. Insight, trendek, vásárlók.” Akadémiai Kiadó, Budapest.

[18] Mintel (2005): "Marketing to Families.", Mintel International Group Ltd, London.

[19] Mintel (2005): "Marketing to Families.”, Mintel International Group Ltd, London.

[20] N. Malhotra, (2008): "Marketingkutatás." Akadémiai Kiadó, Budapest.

[21] P. A. Fisher, L. D. Leve, C. C. O'Leary, \& C. Leve, (2003). „Parental monitoring of children's behavior: Variation across stepmother, stepfather, and two-parent biological families." Family Relations, 52, 45-52.

[22] P. L. Papernow, (1984): "The stepfamily Cycle: An experimental model of stepfamily development.", Family Relations 33(3), pp. 355-363.

[23] R. L. Barker, (2003): "The social work dictionary." (5th ed.) Washington DC: NASW Press.

[24] T. J. Biblarz, and G. Gottainer, (2000): "Family structure and children's success: a comparison of widowed and divorced single-mother families.", Journal of Marriage and Family, Vol. 62, PP 533-548. 
[25] V. Krähenbühl, H. Jellouschek, M. Kohaus-Jellouschek, Kohaus-Jellouschek, R. M-Weber, (2001): „Stieffamilien. Struktur-Entwicklung-Therapie.”, Lambertus Verlag.

[26] V. Krähenbühl, H. Jellouschek, M. Kohaus-Jellouschek, R. Kohaus-Jellouschek, M-Weber, (2001): „Stieffamilien. Struktur-Entwicklung-Therapie.”, Lambertus Verlag.
[27] W. Bien, A. Hartl, and M. Teubner, (2002): „Stieffamilien in Deutschland. Eltern und Kinder zwischen Normalität und Konflikt." Opladen: Leske und Budrich.

[28] Zs. Spéder (ed.) (2003): „Család és népesség - itthon és Európában.” KSH, Budapest. 